\title{
Front Matter: Volume 6653
}

, "Front Matter: Volume 6653," Proc. SPIE 6653, Linear and Nonlinear Optics of Organic Materials VII, 665301 (28 September 2007); doi:

$10.1117 / 12.773752$

SPIE Event: Photonic Devices + Applications, 2007, San Diego, California, United SPIE. States 


\section{PROCEEDINGS OF SPIE}

\section{Linear and Nonlinear Optics of Organic Materials VII}

Jean-Michel Nunzi

Editor

28-30 August 2007

San Diego, California, USA

Sponsored and Published by

SPIE

Volume 6653 
The papers included in this volume were part of the technical conference cited on the cover and title page. Papers were selected and subject to review by the editors and conference program committee. Some conference presentations may not be available for publication. The papers published in these proceedings reflect the work and thoughts of the authors and are published herein as submitted. The publisher is not responsible for the validity of the information or for any outcomes resulting from reliance thereon.

Please use the following format to cite material from this book:

Author(s), "Title of Paper," in Linear and Nonlinear Optics of Organic Materials VII, edited by JeanMichel Nunzi, Proceedings of SPIE Vol. 6653 (SPIE, Bellingham, WA, 2007) Article CID Number.

ISSN 0277-786X

ISBN 9780819468017

Published by

SPIE

P.O. Box 10, Bellingham, Washington 98227-0010 USA

Telephone +1 3606763290 (Pacific Time) · Fax +1 3606471445

SPIE.org

Copyright (C 2007, Society of Photo-Optical Instrumentation Engineers

Copying of material in this book for internal or personal use, or for the internal or personal use of specific clients, beyond the fair use provisions granted by the U.S. Copyright Law is authorized by SPIE subject to payment of copying fees. The Transactional Reporting Service base fee for this volume is $\$ 18.00$ per article (or portion thereof), which should be paid directly to the Copyright Clearance Center (CCC), 222 Rosewood Drive, Danvers, MA 01923. Payment may also be made electronically through CCC Online at copyright.com. Other copying for republication, resale, advertising or promotion, or any form of systematic or multiple reproduction of any material in this book is prohibited except with permission in writing from the publisher. The CCC fee code is $0277-786 \times / 07 / \$ 18.00$.

Printed in the United States of America.

Publication of record for individual papers is online in the SPIE Digital Library.

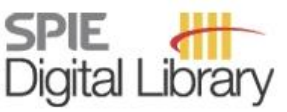

SPIEDigitallibrary.org

Paper Numbering: Proceedings of SPIE follow an e-First publication model, with papers published first online and then in print and on CD-ROM. Papers are published as they are submitted and meet publication criteria. A unique, consistent, permanent citation identifier (CID) number is assigned to each article at the time of the first publication. Utilization of CIDs allows articles to be fully citable as soon they are published online, and connects the same identifier to all online, print, and electronic versions of the publication. SPIE uses a six-digit CID article numbering system in which:

- The first four digits correspond to the SPIE volume number.

- The last two digits indicate publication order within the volume using a Base 36 numbering system employing both numerals and letters. These two-number sets start with 00, 01, 02, 03, 04, 05, $06,07,08,09,0 A, 0 B \ldots 0 Z$, followed by $10-12,20-2 Z$, etc.

The CID number appears on each page of the manuscript. The complete citation is used on the first page, and an abbreviated version on subsequent pages. Numbers in the index correspond to the last two digits of the six-digit CID number. 


\section{Contents}

vii Conference Committee
ix Introduction

\section{KEYNOTE PRESENTATION}

665302 Photonic superlattices for photonic crystal lasers (Keynote Paper) [6653-01]

K. Clays, K. Baert, M. Van der Auweraer, R. Vallée, Katholieke Univ. Leuven (Belgium)

\section{ORGANIC LASERS}

665304 First order distributed feedback dye laser effect in reflection pumping geometry for nonlinear optical measurements [6653-03]

F. Chen, D. Gindre, Lab. POMA, Univ. d'Angers (France); J.-M. Nunzi, Lab. POMA, Univ. d'Angers (France) and Queen's Univ. (Canada)

665305 Photoresponsive polymers containing side-chain chiral azocarbazole chromophores as multifunctional materials (Invited Paper) [6653-55]

L. Angiolini, Univ. degli Studi di Bologna (Italy); R. Bozio, T. Dainese, Univ. di Padova (Italy);

L. Giorgini, Univ. degli Studi di Bologna (Italy); A. Golemme, Univ. della Calabria (Italy);

F. Mauriello, Univ. degli Studi di Bologna (Italy); D. Pedron, Univ. di Padova (Italy); R.

Termine, Lab. Licryl, CNR-INFM, e Centro di Eccellenza, CEMIF.CAL (Italy)

\section{MULTIPHOTON EFFECTS}

665307 Broad bandwidth near-IR two-photon absorption in conjugated porphyrin-core dendrimers [6653-06]

A. Rebane, N. Makarov, M. Drobizhev, Montana State Univ. (USA); C. W. Spangler, Montana State Univ. (USA) and Rasiris, Inc. (USA); A. Gong, F. Meng, Rasiris, Inc. (USA)

665308 High sensitivity photo-thermal lens method for measurement of two-photon absorption [6653-07]

A. Marcano O., K. Williams, N. Melikechi, Delaware State Univ. (USA)

\section{OPTICAL COMPONENTS}

6653 OD Effect of silicon dioxide nanoparticles on the characteristics of PQ/PMMA holographic filters [6653-13]

J. M. Russo, J. E. Castillo, R. K. Kostuk, The Univ. of Arizona (USA)

6653 OG Fiber optic transmission of analog signals [6653-16]

R. Furukawa, K. Uehara, Keio Univ. (Japan) and Japan Science and Technology Agency (Japan); S. Takahashi, N. Ohtsu, Japan Science and Technology Agency (Japan); Y. Koike, Keio Univ. (Japan) and Japan Science and Technology Agency (Japan) 
$6653 \mathrm{OH}$ Modal analysis of organic-inorganic hybrid planar waveguides for integrated optics [6653-17]

L. Penedo Pellegrino, Nokia Siemens Networks Portugal SA (Portugal) and Univ. de Aveiro (Portugal); P. André, Univ. de Aveiro (Portugal) and Instituto de Telecomunicações (Portugal); R. A. Sá Ferreira, L. Carlos, Univ. de Aveiro (Portugal); C. Vicente, Univ. de Aveiro (Portugal) and Instituto de Telecomunicações (Portugal); P. Monteiro, Nokia Siemens Networks Portugal SA (Portugal) and Univ. de Aveiro (Portugal)

\section{PHOTO-INDUCED EFFECTS}

$66530 \mathrm{~J}$ A new mechanism of relaxation in poled guest-host systems: Monte Carlo analysis of aggregation scenario (Invited Paper) [6653-19]

G. Pawlik, D. Wronski, A. C. Mitus, Wroclaw Univ. of Technology (Poland); I. Rau, Politehnica Univ. of Bucharest (Romania); C. Andraud, Ecole Normale Superieure, Lyon (France);

F. Kajzar, Lab. POMA, CNRS, Univ. d'Angers (France)

6653 OK Photoinduced twisting behavior of chiral cyclic compounds (Invited Paper) [6653-20] M. Kawamoto, T. Aoki, T. Wada, RIKEN (Japan)

$6653 \mathrm{OL}$ Stability of all-optical poling in hydrogen-bonded guest-host polymers [6653-21] F. J. Rodriguez, I. Kettunen, Tampere Univ. of Technology (Finland); A. Priimagi, Helsinki Univ. of Technology (Finland); M. Kauranen, Tampere Univ. of Technology (Finland)

\section{NONLINEAR DEVICES}

6653 ON Multifunctional polyimides for tailorable high-performance electro-optical devices (Invited Paper) [6653-23]

A. J. Guenthner, M. E. Wright, S. Fallis, G. R. Yandek, B. J. Petteys, J. J. Cash, Naval Air Warfare Ctr. (USA); D.-Y. Zang, C. Gaeta, M. Zounes, Ipitek, Inc. (USA)

665300 Modeling and prediction of relaxation of polar order in high-activity nonlinear optical polymers [6653-24]

A. J. Guenthner, G. A. Lindsay, M. E. Wright, S. Fallis, Naval Air Warfare Ctr. (USA);

P. R. Ashley, M. Sanghadasa, U.S. Army Research, Development, and Engineering Command (USA)

6653 OP Optical bistability of terthiophene/polymethylmethacrylate composite film [6653-25] S. Mototani, S. Ochiai, K. Kojima, T. Mizutani, Aichi Institute of Technology (Japan)

$6653 \mathrm{OQ}$ Low half-wave voltage modulators using nonlinear optical polymers [6653-26]

D. Jin, D. Huang, B. Chen, H. Chen, L. Zheng, A. Barklund, G. Yu, E. Miller, M. Moolayil, B. Li,

R. Dinu, Lumera Corp. (USA) 
6653 OR Structure-property relationship in organometallic compounds regarding SHG (Invited Paper) [6653-27]

J. Heck, M. H. Prosenc, T. Meyer-Friedrichsen, J. Holtmann, E. Walczuk, M. Dede, Univ. of Hamburg (Germany); T. Farrell, A. R. Manning, Univ. College Dublin (Ireland); H.-G. Kuball, G. Archetti, Univ. of Kaiserslautern (Germany); Y.-H. Wang, K. Liu, Y. Luo, Royal Institute of Technology (Sweden)

6653 OU Optical absorption and SHG in PMMA:DR1 thin films as function of poling time [6653-30] J. A. García-Macedo, A. Franco, G. Valverde-Aguilar, C. Aguilar-Gutiérrez, Univ. Nacional Autónoma de México (Mexico)

MOLECULAR ENGINEERING

6653 OV Quantum spectroscopy of an organic material utilizing entangled and correlated photon pairs (Invited Paper) [6653-31]

D.-I. Lee, T. Goodson III, Univ. of Michigan (USA)

6653 OW Modulated conjugation for record-high intrinsic hyperpolarizabilities [6653-32]

J. Pérez-Moreno, K. Clays, Univ. of Leuven (Belgium); M. G. Kuzyk, Washington State Univ.

(USA); Y. Zhao, Y. Shen, L. Qiu, J. Hao, Technical Institute of Physics and Chemistry (China)

6653 OX NLO properties of dithienothiophene-based chromophores: a comparison study between the donor/donor and donor/acceptor substitution patterns [6653-33]

M. C. Ruiz Delgado, Georgia Institute of Technology (USA) and Univ. of Málaga (Spain);

J. Casado, V. Hernández, J. T. López Navarrete, Univ. of Málaga (Spain); O.-K. Kim,

H. Y. Woo, Naval Research Lab. (USA); B. Villacampa, R. Alicante, J. Orduna, J. Garín, Univ.

of Zaragoza-CSIC (Spain)

\section{POSTER SESSION}

$66530 Z$ Detection of alterations in human sperm using magnetic orientation techniques [6653-37]

L. Sakhnini, M. Dairi, Univ. of Bahrain (Bahrain); H. Manaa, Kuwait Univ. (Kuwait)

665310 Possibility of using Rhodamine B dye in diagnosis of some men's diseases [6653-38]

G. Khodjayev, Samarkand Agriculture Institute (Uzbekistan); Z. F. Ismailov, E. N. Kurtaliev, N. Nizomov, F. U. Khaydarova, Samarkand State Univ. (Uzbekistan); Z. Hamidov, Special Medical Ctr. (Uzbekistan); D. P. Khakimova, Samarkand Polyclinic No. 3 (Uzbekistan)

665312 Completely passive nonlinear transmission system using a nonlinear absorbing medium and azobenzene films [6653-42]

C. S. Yelleswarapu, D. V. G. L. N. Rao, Univ. of Massachusetts, Boston (USA); B. R. Kimball, U.S. Army Natick Soldier Research Development and Engineering Ctr. (USA)

665313 Enhanced photoinduced birefringence in hydrogen-bonded guest-host polymers [6653-43] A. Priimagi, Helsinki Univ. of Technology (Finland); F. J. Rodriguez, M. Kauranen, Tampere Univ. of Technology (Finland); M. Kaivola, Helsinki Univ. of Technology (Finland) 
665314 New sol-gel materials for high energy applications in nonlinear optics [6653-44]

I. Fortunati, R. Signorini, R. Bozio, G. Brusatin, M. Guglielmi, Univ. of Padova (Italy)

665317 Ultrafast excitation dynamics in organic multicromophoric systems after two-photon excitation [6653-48]

O. Varnavski, T. Goodson III, Univ. of Michigan (USA); P. Bäuerle, Ulm Univ. (Germany)

6653 1C Synthesis and chiroptical properties of methacrilic copolymers containing in side-chain optically active carbazole and azochromophores [6653-54]

L. Angiolini, T. Benelli, L. Giorgini, F. Mauriello, E. Salatelli, Univ. degli Studi di Bologna (Italy)

Author Index 


\title{
Conference Committee
}

\author{
Symposium Chair
}

Zakya H. Kafafi, Naval Research Laboratory (USA)

Conference Chair

Jean-Michel Nunzi, Laboratoire POMA, Université d'Angers (France) and Queen's University (Canada)

\section{Conference Cochairs}

Rachel Jakubiak, Air Force Research Laboratory (USA)

Theodore G. Goodson III, University of Michigan (USA)

Manfred Eich, Technische Universität Hamburg-Harburg (Germany)

Program Committee

Kevin D. Belfield, University of Central Florida (USA)

Antao Chen, University of Washington (USA)

Koen J. Clays, Katholieke Universiteit Leuven (Belgium)

Alain F. Fort, Institut de Physique et Chimie des Matériaux de Strasbourg (France)

Francois Kajzar, Université d'Angers (France)

Satoshi Kawata, Osaka University (Japan)

Mark G. Kuzyk, Washington State University (USA)

Charles Y. C. Lee, Air Force Office of Scientific Research (USA)

Kwang-Sup Lee, Hannam University (South Korea)

Geoffrey A. Lindsay, Naval Air Warfare Center (USA)

Aristides A. Marcano O., Delaware State University (USA)

Robert A. Norwood, College of Optical Sciences, The University of Arizona (USA)

André P. Persoons, College of Optical Sciences, The University of Arizona (USA)

Jayan Thomas, College of Optical Sciences, The University of Arizona (USA)

Tatsuo Wada, The Institute of Physical and Chemical Research (Japan)

A. Todd Yeates, Air Force Research Laboratory (USA)

Session Chairs

1 Organic Lasers

Theodore G. Goodson III, University of Michigan (USA) 
2 Multiphoton Effects

Jean-Michel Nunzi, Laboratoire POMA, Université d'Angers (France) and Queen's University (Canada)

3 Microstructures

Aristides A. Marcano O., Delaware State University (USA)

4 Optical Components

Alain F. Fort, Institut de Physique et Chimie des Matériaux de Strasbourg (France)

5 Photo-Induced Effects

Rachel Jakubiak, Air Force Research Laboratory (USA)

$6 \quad$ Nonlinear Devices

Koen J. Clays, Katholieke Universiteit Leuven (Belgium)

$7 \quad$ Second Order Effects

Robert A. Norwood, College of Optical Sciences, The University of Arizona (USA)

$8 \quad$ Molecular Engineering

Robert A. Norwood, College of Optical Sciences, The University of Arizona (USA) 


\section{Introduction}

This year's conference on Linear and Nonlinear Optics of Organics VII confirmed the renewed interest observed last year, with 12 posters and 32 oral talks including nine invited and one topical paper.

Topics spanned the range of disciplinary activities required to design, synthesize, and characterize the properties of new organic-based optical materials, focusing on second-/third-order, and multiphoton nonlinear optical effects as well as novel organic material concepts and materials enabling the demonstration of entirely new devices and phenomena. Equally important topics include progress in the development of processing conditions, fabrication technology, and devicerelated research and emerging application areas employing these new materials.

Emphasis was placed on the interdisciplinary nature of this field and the range of chemistry, materials science, physics, optics, and engineering mastery required for technological success. This conference focused on how the linear and nonlinear optical properties of organic materials impact their use in both guided wave and through-the-plane optical devices. Recent developments in the area of nanophotonic structures, such as active photonic crystals based on organic materials, were of special interest.

New materials that exhibit exceptionally low optical losses at communications wavelengths were also of interest. In parallel, the conference improved the understanding of higher order optical functionality through the study of the relationship between the molecular optical properties and the macroscopic second- and third-order nonlinear optical susceptibilities. Organic materials manifesting new properties such as chiral effects were examples of an emerging area of concentration. There were reports on secondary properties such as polarization effects, temperature/humidity dependence, stress-optical properties, and optical power handling, highlighted potential device performance and reliability issues. Discussion of device performance and manufacturing techniques took place, especially devices or manufacturing techniques that are uniquely enabled by novel organic materials.

The merger with the Quantum Optical Effects in Organic Materials conference was a success. We envision next year converting the session on organic and polymer lasers into a joint session with the Organic Light-Emitting Materials and Devices conference.

Jean-Michel Nunzi 
Downloaded From: https://www.spiedigitallibrary.org/conference-proceedings-of-spie on 26 Apr 2023

Terms of Use: https://www.spiedigitallibrary.org/terms-of-use 